\title{
Effects of pentoxifylline on proliferation of human umbilical vein endothelial cells (HUVEC)
}

\section{Pentoksifilinin insan göbek bağ|l veni endotel hücrelerinin (HUVEC) proliferasyonu üzerine etkisi}

Eyup Çağatay Zengin ${ }^{1}$, Zübeyde Akın Polat ${ }^{2}$, Ali Çetin ${ }^{3}$

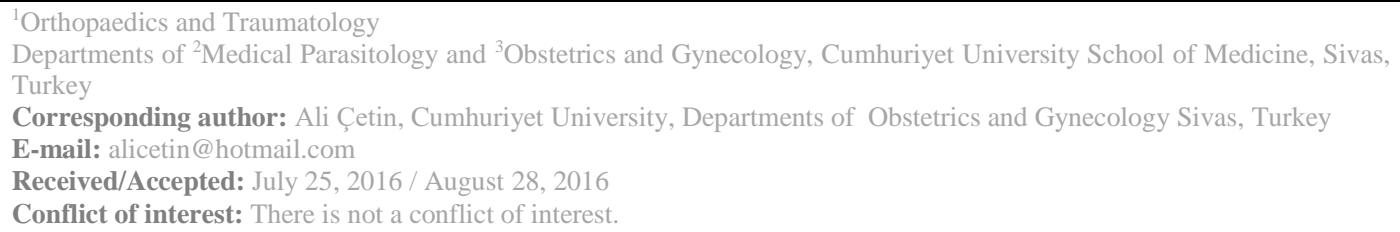

\section{SUMMARY}

Objective: The aim of this study was to investigate the effect of pentoxifylline (PNX) with a pharmacological dose range on proliferation of human umblical venous endothelial cells (HUVEC). Method: The cells were maintained in M199 supplemented with 20\% fetal bovine serum, penicillin, and streptomycin. The cultures were cultivated in an incubator at $37^{\circ} \mathrm{C}$ and with $5 \% \mathrm{CO}_{2}$, until cell monolayers attained confluence which occurred after 7 days. The assays were performed in the exponential growth phase of the cells. The cell viability was assessed using the cleavage of tetrazolium salts added to the culture medium. Pentoxifylline with concentrations of $10^{-4} \mathrm{M}, 10^{-5} \mathrm{M}$, $10^{-6} \mathrm{M}$ and $10^{-7} \mathrm{M}$ were used for the proliferation assay in which cells were incubated for 24,48 , and 72-hours with these drugs. The experiments were conducted in six replicates.

Results: Only the $10^{-4} \mathrm{M}$ dose of PNX at $72 \mathrm{~h}$ significantly reduced the viability of HUVEC $(\mathrm{p}<0.05)$ and except this, there was no cytotoxic effect of PTX on HUVEC in a dose- and time- dependent manner $(\mathrm{p}>0.05)$.

Conclusions: Overall, PTX with a pharmacological dose range has no cytotoxic effect on HUVEC. We think that this is also in accordance with the findings of several studies performed in animal models and clinical settings, indicating positive effects of PTX on tissues in normal and ischemic conditions.

Keywords: Pentoxifylline, proliferation, human umbilical venous endothelial cells

\section{ÖZET}

\begin{abstract}
Amaç: Bu çalışmanın amacı farmokolojik doz aralığında uygulanan pentoksifilinin insan umblikal ven endotel hücrelerinin (HUVEC) proliferasyonu üzerine etkisini araştırmaktır.

Yöntem: Hücreler içerisine \%20 fetal bovine serum, penisilin ve streptomisin eklenen M199 besiyeri içinde, $\% 5 \mathrm{CO}_{2}$ içeren $37^{\circ} \mathrm{C}$ 'lik inkübatörde kültüre edildi. Deneyler hücreler gelişim fazında iken gerçekleştirildi. Hücrelerin canlılığı kültür ortamına tetrazolium tuzları eklenerek değerlendirildi. Pentoksifilinin $10^{-4} \mathrm{M}, 10^{-5} \mathrm{M}, 10^{-6} \mathrm{M}$ and $10^{-7} \mathrm{M}$ konsantrasyonlar1, 24, 48 ve 72. saatlerde değerlendirildi. Deneyler altı tekrarlı yapıld1.

Bulgular: Pentoksifilinin sadece $10^{-4} \mathrm{M}$ dozu 72. saatte HUVEC proliferasyonunu düşürdü $(p<0.05)$, diğer dozlar zamana ve doza bağlı olarak herhangi bir sitotoksik etki göstermedi $(p>0.05)$. Sonuç: Genel olarak, pentoksifilinin farmakolojik dozlar aralığında HUVEC hücreleri üzerine
\end{abstract}


sitotoksik etkisi bulunmamaktadır. Bu sonuç, pentoksifilinin normal ve iskemik dokulardaki pozitif etkilerini gösteren çeşitli deneysel ve klinik araştırmaların sonuçları ile uyumlu bulunmaktadır. Anahtar sözcükler: Pentoksifilin, proliferasyon, insan göbek bağı veni endotel hücreleri

\section{INTRODUCTION}

Pentoxifylline (PTX), a nonspecific phosphodiesterase inhibitor, was first considered in the treatment of peripheral vascular diseases. PTX exerts several pharmacologic effects, including improvement in microcirculation, increase in erythrocyte deformability, reduction in blood viscosity, inhibition of platelet aggregation, endotheliumdependent vascular relaxation, immunomodulatory, anti-inflammatory, and antiproliferative effects ${ }^{1-4}$.

The growing appreciation of endothelium as a target of inflammation as well as a source of inflammatory mediators lead to ongoing research to shed light on the pathophysiology of several chronic disorders. Endothelial injury after ischemia and reperfusion is characterized by an increase in permeability, cellular edema, and loss of acetylcholinemediated vasorelaxation ${ }^{5}$. There are several studies examined the preventive effect of PTX on endothelial damage in laboratory conditions as ischemia reperfusion studies ${ }^{5-8}$.

Although beneficial effects of PTX have demonstrated on disorders related to the microcirculation of tissues, the mechanisms by which PTX exerts a protective effect are not fully understood $^{9}$. In the pertinent literature, there are studies investigated the effect of PTX on human umbilical vein endothelial cells (HUVEC); however, in the majority of them, PTX is used as an adjunct to other study drugs to examine their effects ${ }^{10,11}$.

HUVEC have been used as an important in vitro model for hemostasis, angiogenesis and immunological investigations. We think that the efeects of PTX need to be examined to understand its effect after administered with a pharmacological dose range. This can improve the usage of PTX in optimal dose in further studies and reliability of results obtained with them. The aim of this in vitro study was to investigate the effect of pentoxifylline with a pharmacological dose range on viability of HUVEC.

\section{MATERIAL AND METHODS}

Drug

In this study we investigated the effects of a vasodilating agent, PTX (Trental ${ }^{\circledR}$ $300 \mathrm{mg} / 15 \mathrm{ml}$, Sanofi Aventis Drug Company, Istanbul) on human umbilical vein endothelial cells (HUVEC) proliferation. PTX was used in the form of solubleinfusion. Appropriate volumes of solutions were used to achieve three different concentrations of the drug (10 $\left.{ }^{4} \mathrm{M}, 10^{-5} \mathrm{M}, 10^{-6} \mathrm{M}, 10^{-7} \mathrm{M}\right)$. Due to lack of adequate knowledge, the choice of these concentrations could not be based on the results of the previous studies $[10,11]$. So we tried to use wide range of drug concentrations and these concentrations were based on the knowledge that therapeutic concentrations of drugs at treatment side are $10^{-5} \mathrm{M}$ to $10^{-6} \mathrm{M}$. First of all, a concentration of $10^{-4} \mathrm{M}$ of the drug was prepared and more diluted concentrations were prepared by diluting these solutions.

Cultivation of HUVEC cells

Human umbilical venous endothelial cells were obtained from the American Type Culture Collection. The cells were maintained in a gelatin-coated $75-\mathrm{cm}^{2}$ flask in M199 (Sigma, St. Louis, MO, USA) supplemented with $20 \%$ fetal bovine serum (FBS, Sigma, St. Louis, MO, USA), 100 units $\mathrm{ml}^{-1}$ penicillin, 100 $\mathrm{mg} \mathrm{ml}{ }^{-1}$ streptomycin, and $3 \mathrm{ng} \mathrm{ml}^{-1}$ basic fibroblast growth factor (bFGF) (Life Technologies Inc., Rockville, MD, USA). The cultures were cultivated in an incubator at $37^{\circ} \mathrm{C}$ and with $5 \% \mathrm{CO} 2$, until cell monolayers attained confluence which occurred after 7 days. Assays were performed in the exponential growth phase of the cells. 
Cell proliferation assays

The cell viability was assessed using the cleavage of tetrazolium salts added to the culture medium, using the WST-1 labeling reagent (Roche, Mannheim, Germany). During the assay, tetrazolium salts are cleaved to formazan by cellular enzymes. An expansion in the number of viable cells results in an increase in the overall activity of mitochondrial dehydrogenases in the sample. This augmentation in enzyme activity leads to an increase in the amount of formazan dye formed, which correlates directly with the number of metabolically active cells in the culture. The formazan dye produced by the metabolically active cells was quantified by a scanning multiwell spectrophotometer by measuring the absorbance of the dye solution at $450 \mathrm{~nm}$. Cells were seeded in 96-well gelatin coated microtitre plates at a concentration of $1 \times 104$ cells.mL- 1 in a final volume of $100 \mu \mathrm{L}$ per well.

Cells were then incubated for 24,48 , and $72 \mathrm{~h}$ with drugs in a humidified atmosphere $\left(37^{\circ} \mathrm{C}, 5 \% \mathrm{CO} 2\right)$. After the incubation period, $10 \mu \mathrm{L}$ of the WST-1 labeling reagent were added to $10 \mu \mathrm{L}$ of culture medium in each well, and the absorbance of the samples was measured at $450 \mathrm{~nm}$ against the control (the same cells without any treatment) using a microtitre plate reader (Thermo Scientific Microplate Photometer Multiskan FC, Waltham, MA, USA). The same volume of culture medium and WST-1 labeling reagent ( $10 \mu \mathrm{L}$ of WST1 labeling reagent $/ 100 \mu \mathrm{L}$ of culture medium) was added to one well to use as a background control (absorbance of culture medium plus WST-1 in the absence of cells) as a blank position for the microtitre plate reader. The absorbance was measured after $2 \mathrm{~h}$ from the start of the tetrazolium reaction. The experiments were conducted in six replicates.

The viability of the control group was defined as $100 \%$ and viability of the study drugs on HUVEC were calculated with respect to their negative controls. In this manner the optical density (OD) of the samples was compared to that of their negative controls to obtain the viability score, as follows: viability score (\%, relative to control $)=[(\mathrm{OD} 450($ sample $) /$ OD450 (negative control) $) \times 100]$.

\section{Statistical analysis}

Data were presented as mean \pm SD from six replicates. Mean viability ratios with a dose- and time- dependent manner were compared by using repeated measures ANOVA with Tukey post hoc test. Statistical significance was established at $\mathrm{p}<0.05$.

\section{RESULTS}

The cytotoxicity of PTX at the doses from $10^{-4} \mathrm{M}$ to $10^{-7} \mathrm{M}$ was tested for 24 , 48 , and $72 \mathrm{~h}$ by quantitative analysis using the WST-1 test. The viability ratios for the study doses of PTX against the control were calculated (Figure 1). The dose- and time- dependent effects of PTX on the viability of HUVEC were examined. According to results of repeated measures ANOVA, only the $10^{-}$ ${ }^{4} \mathrm{M}$ dose of PNX at $72 \mathrm{~h}$ significantly reduced the viability of HUVEC $(p<0.05)$ and except this, there was no cytotoxic effect of PTX on HUVEC in a dose- and time- dependent manner ( $p>0.05)$. There was no significant difference among the other doses at $72 \mathrm{~h}$ with regard to the PNX cytotoxicity ( $p>0.05)$. There was no significant difference among the PNX doses at 24 and $48 \mathrm{~h}$ with regard to the PNX cytotoxicity ( $p>0.05)$. 


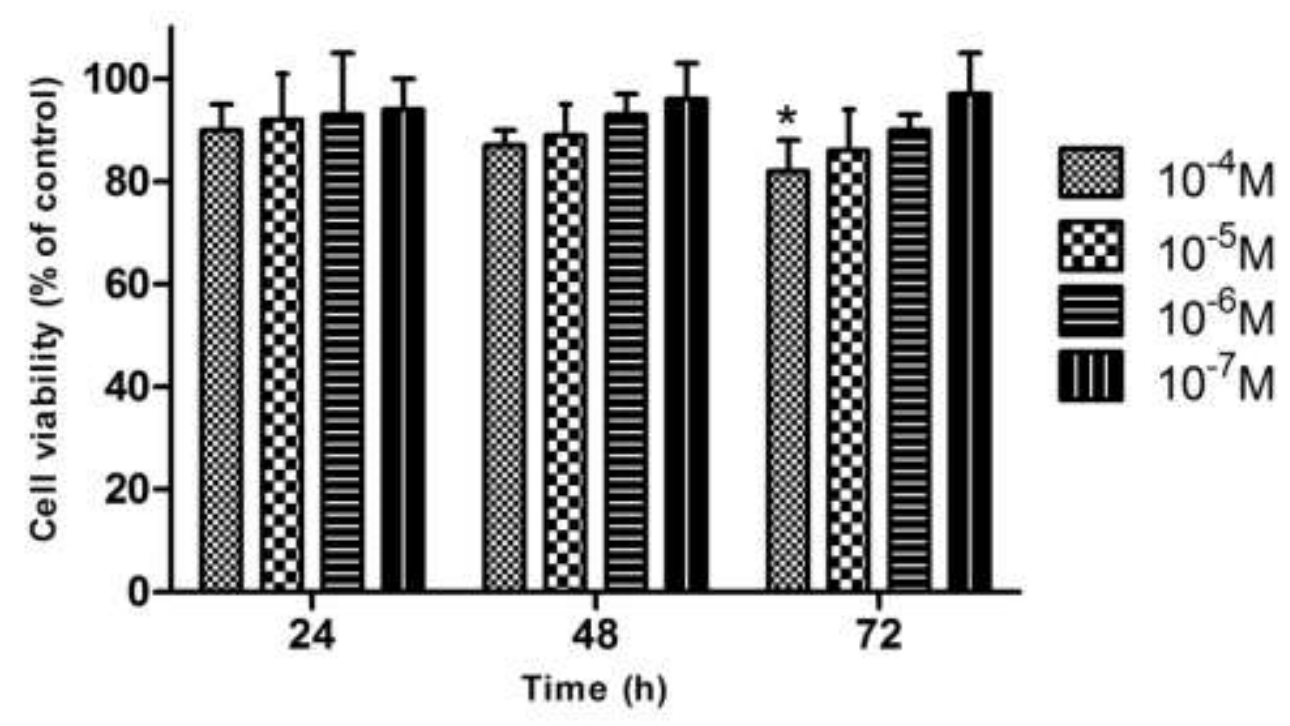

Figure 1. In vitro cytotoxicity of PNX was tested for 24,48 , and 72 h by quantitative analysis using the WST-1 assay. Data were presented as mean \pm SD. There was no significant difference among the PNX doses at 24 and $48 \mathrm{~h}$ with regard to PNX cytotoxicity. *Significantly different as compared other doses at $72 \mathrm{~h}$ with regard to PNX cytotoxicity $(\mathrm{P}<0.05)$. There was no significant difference among the other doses at $72 \mathrm{~h}$ with regard to PNX cytotoxicity.

\section{DISCUSSION}

PTX, a methylxanthine compound, has been under use since its registration in 1974 in the United States by SanofiAventis Deustchland Gmbh with the indication of intermittent claudication in patients with chronic occlusive arterial disease. This drug was later added to phosphodiesterase inhibitors. Therefore, several studies demonstrated its hemorheological properties as well as an inhibitor of inflammatory cytokines ${ }^{9}$.

In recent years, there is an increased interest to PTX as a study drug in ischemia and reperfusion studies ${ }^{8,9,12}$. Genovés et al. ${ }^{9}$ reviewed the status of PTX on ischemia and reperfusion studies in liver and they noted that PTX has a potential to be used as a preventive drug and its effect seems to related to mainly TNFalpha. Taha et al. ${ }^{13}$ investigated the role of heme oxygenase-1 (HO-1) induction on anti-inflammatory activity of PTX and they concluded that there is no relationship of this enzyme with the anti-imflammatory effect of PTX.
Gude et al. ${ }^{14}$ conducted a study to investigate the effect of PTX on endothelial cell proliferation and tumorinduced angiogenesis. In their study, they injected intradermally 10 B16-F10 melanoma cells into C57BL/6J mice. Then they were subsequently inoculated with PTX. They observed that there was considerable inhibition of tumor-induced angiogenesis in C57B1/6 mice after the use of PTX and this finding was found as parallel with the reduced incipient tumor volumes. The endothelial cells derived from different sources were inhibited in a dose-response manner by PTX in vitro. They concluded that that the inhibitory effect of PTX on tumor angiogenesis is related to antiproliferative action on endothelial cells. Contrary to their findings supporting the antiproliferative action on endothelial cells, in our study, PTX has no meaningful effect on viability of HUVEC. In our study, we used solely PTX with a pharmacological range and measured the effect of PTX in a time-dependent manner. Except $10^{-4} \mathrm{M}$ PTX at $72 \mathrm{~h}$, there was no cytotoxicity in 
HUVEC. We think that further studies with different cell lines need to be performed to clarify the effect of PTX.

In our laboratory setting, overall, PTX with a pharmacological dose range has no cytotoxic effect on HUVEC. We think that our data also support the findings of several studies performed in animal models and clinical settings, indicating positive effects of PTX on tissues in normal and ischemic conditions. There is need for further research to shed light on the mechanisms of its effect on other cell lines including endothelial cells.

\section{REFERENCES}

1. Nasiri-Toosi Z, Dashti-Khavidaki S, Khalili H, Lessan-Pezeshki M. A review of the potential protective effects of pentoxifylline against drug-induced nephrotoxicity. Eur J Clin Pharmacol 2013; 69: 1057-73.

2. Samlaska CP, Winfield EA. Pentoxifylline. J Am Acad Dermatol 1994; 30: 603-21.

3. Kreth S, Ledderose C, Luchting B, Weis $F$, Thiel M. Immunomodulatory properties of pentoxifylline are mediated via adenosine-dependent pathways. Shock 2010; 34: 10-6.

4. Savic V, Vlahovic P, Djordjevic V, Mitic-Zlatkovic M, Avramovic V, Stefanovic V. Nephroprotective effects of pentoxifylline in experimental myoglobinuric acute renal failure. Pathol Biol (Paris) 2002; 50: 599-607.

5. Coe DA, Freischlag JA, Johnson D, Mudaliar JH, Kosciesza SA, Traul DK, Chiang PC, Cambria RA, Seabrook GR, Towne JB. Pentoxifylline prevents endothelial damage due to ischemia and reperfusion injury. J Surg Res 1997; 67: 21-5.

6. Normandin L, Hervé P, Brink C, Chapelier AR, Dartevelle PG, Mazmanian GM. L-arginine and pentoxifylline attenuate endothelial dysfunction after lung reperfusion injury in the rabbit. The Paris-Sud University Lung Transplant Group. Ann Thorac Surg 1995; 60: 646-50.
7. Dauber IM, Lesnefsky EJ, Ashmore RC, Martel DM, Sheridan FM, Weil JV, Horwitz LD. Coronary vascular injury due to ischemia-reperfusion is reduced by pentoxifylline. $\mathbf{J}$ Pharmacol Exp Ther 1992; 260: 1250-6.

8. Teruya R, Fagundes DJ, Oshima CT, Brasileiro JL, Marks G, Ynouye CM, Simões MJ. The effects of pentoxifylline into the kidneys of rats in a model of unilateral hindlimb ischemia/reperfusion injury. Acta Cir Bras 2008; 23: 2935.

9. Genovés P, García D, Cejalvo D, Martin A, Zaragoza C, Toledo AH, Toledo-Pereyra LH, Lloris-Carsi JM. Pentoxifylline in liver ischemia and reperfusion. J Invest Surg. 2014; 27: 114-24.

10. Hoie EB, McGuire TR, Leuschen PM, Zach TL. Pentoxifylline inhibits tumor necrosis factor-alpha induced synthesis of complement component $\mathrm{C} 3$ in human endothelial cells. Biol Pharm Bull 2004; 27: 1670-3.

11. Franzini E, Sellak H, BabinChevaye C, Hakim J, Pasquier C. Effects of pentoxifylline on the adherence of polymorphonuclear neutrophils to oxidant-stimulated human endothelial cells: involvement of cyclic AMP. J Cardiovasc Pharmacol 1995; 25: 92-5.

12. Lloris Carsi JM, Cejalvo Lapeña D, Toledo AH, Zaragoza Fernandez C, Toledo Pereyra LH. Pentoxifylline protects the small intestine after severe ischemia and reperfusion. Exp Clin Transplant 2013; 11: 2508.

13. Taha H, Grochot-Przeczek A, Was H, Kotlinowski J, Kozakowska M, Marek A, Skrzypek K, Lackowska B, Balcerczyk A, Mustafa S, Dulak $\mathrm{J}$, Jozkowicz A. Modulation of inflammatory response by pentoxifylline is independent of heme oxygenase-1 pathway. $\mathrm{J}$ Physiol Pharmacol 2009; 60: 3-12. 
14. Gude RP, Binda MM, Boquete AL,

Bonfil RD. Inhibition of endothelial cell proliferation and tumor-induced angiogenesis by pentoxifylline. J Cancer Res Clin Oncol 2001; 127: 625-30. 